\title{
EVALUATION OF SURGICAL CAVITIES FILLED WITH THREE TYPES OF CALCIUM SULFATE
}

\author{
Sergio Toshinori MAEDA ${ }^{1}$, Clovis Monteiro BRAMANTE ${ }^{2}$, Rumio TAGA ${ }^{3}$, Roberto Brandão GARCIA ${ }^{4}$, \\ Ivaldo Gomes de MORAES ${ }^{4}$, Norberti BERNADINELI ${ }^{4}$
}

1-DDS, MSc, Department of Endodontics, Metodista Dental School, University Metodista of São Paulo, São Bernardo do Campo-SP, Brazil.

2- DDS, MSc, PhD, Department of Endodontics-Bauru Dental School, University of São Paulo, Bauru-SP, Brazil.

3- DDS, PhD,Department of Biological Sciences, Bauru Dental School, University of São Paulo, Bauru-SP, Brazil.

4- DDS, MSc, Department of Endodontics-Bauru Dental School, University of São Paulo, Bauru-SP, Brazil.

Corresponding address: Prof. Dr. Clovis Monteiro Bramante - Al. Octávio Pinheiro Brisola n 9-75 - 17012-901, Bauru, São Paulo, Brasil.

Phone: 55-14-32358344 - e-mail-bramante@fob.usp.br

Received: October 19, 2006 - Modification: May 31, 2007 - Accepted: July 13, 2007

\begin{abstract}
$T_{\text {he }}$

he aim of this study was to evaluate histologically, three types of calcium sulfate - Merck (Brazil), Surgiplaster (Italy) and Capset (USA) - in surgically created defects on rabbit femurs. Twenty male New Zealand rabbits were used. Two surgical bone defects (5 mm diameter x $8 \mathrm{~mm}$ depth) were created on each distal epiphysis using a \#3 Dentoflex trephine bur. Defects were filled with: group 1 - di-hydrated calcium sulfate (Merck); group 2 - Capset (Lifecore-USA); group 3 - Surgiplaster (ClassimportItaly); group 4 - control (blood clot). The animals were sacrificed 30, 60, 90 and 180 days postoperatively. Semi-serial 6-mmthick sections were obtained, stained with hematoxylin and eosin and examined under light microscopy. Bone defects treated with calcium sulfate exhibited new bone formation regardless of the product trademark.
\end{abstract}

Uniterms: Calcium sulfate; Bone defect; Bone regeneration.

\section{INTRODUCTION}

Several surgical procedures using biological or synthetic bone substitutes have been developed for the treatment of bone defects to promote closure with new bone tissue with morphological and functional characteristics similar to those

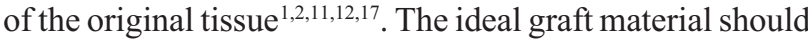
be biocompatible, non antigenic, non carcinogenic, osteoinduction, osteoconductive, low cost and gradual substitute of bone tissue $e^{5,11,14,21,22}$.

The autogenous bone ís the most widely used graft material due its favorable biological properties in terms of the formation of new bone tissue. Nevertheless, the most of the time is unviable due insufficient amounts of autogenous bone, size of defects, disconfort for the patient, the need for extensive and long-lasting surgery to obtain the graft and the risk of infecction at the donor site s $^{13,14,16}$.

Calcium sulfate used as bone implant material has been reviewed by several authors $1,2,3,8,10,12,17,20$. Calcium sulfate or plaster of Paris has a long clinical history as a bone graft material substitute in various skeletal sites including mandibular ${ }^{1}$, craniofacial $^{12}$ and long bone defects ${ }^{10-15}$ and benign bone lesions ${ }^{12}$. Calcium sulfate also has been used as a barrier in guided tissue regeneration by physically halting soft connective tissue proliferation by means of the osteopromotion principle $4,8,18,19,25$

The aim of this study was to evaluate histologically the tissue reaction to three types of calcium sulfate: di-hydrate calcium sulfate (Merck, Brazil), Capset (Lifecore Medicals, USA) and Surgiplaster (Classimport, Italy) when used in surgical cavities on femurs epiphisis rabbits.

\section{MATERIALAND METHODS}

Twenty male New Zealand rabbits aged between 9 and 12 months with body mass between $3.5 \mathrm{~kg}$ and $4.0 \mathrm{~kg}$, obtained from the Central Animal Laboratory of the Dental School of Bauru, USP, were used. The experiment was made in conformity with the Ethical Principles of Animal Experimentation of the Brazilian College of Animal Experimentation (COBEA).

All animals were submitted to surgery under general anesthesia with intra-muscular injection of xylazine/ketamine (AgriBrands Ltda ${ }^{\mathrm{TM}}$, Paulinia, SP, Brazil). After trichotomy of the internal femur region and disinfection with iodine alcohol solution (Povidine), a linear incision was made in the lining epithelium of the tibia-femur junction with \# 15 surgical blade. The flap was elevated with a Molt spatula, exposing the bone surface of the femoral epiphysis. With a 
\#3 surgical trephine bur (Dentoflex), two cavities was created ( $5 \mathrm{~mm}$ in diameter $\mathrm{x} 8 \mathrm{~mm}$ in depth) on each femoral epiphysis (right and left) under copious saline irrigation.

The animals were divided into four groups: group 1 ( 5 animals) the defect was filled with dehydrated calcium sulfate (Merck, Rio de Janeiro, RJ, Brazil); group 2 (5 animals) filled with Capset (Lifecore Biomedicals, Inc., Chaska, MN, USA); group 3 (5 animals) filled with Surgiplaster (Classimport, Italy); group 4 (control group) filled with blood clot.

The materials were mixed with blood taken from the ear lobule and applied in the cavities using a graft carrier. The implants were randomized into the surgical sites. Flap was placed in position and closed with \# 4 Vicryl (Poliglactine 910, Johnson \& Johnson, São José dos Campos, SP, Brazil).

The rabbits were sacrificed with an anesthetic overdose $30,60,90$ and 180 days after surgery. The femoral epiphysis were collected and fixed in $10 \%$ formalin for 1 week, demineralized in Morse solution for 40 days, dehydrated in ethanol, cleared with xylene and embedded in Histosec. The blocks were cut into semi-serial 6-mm-thick sections and stained with hematoxylin and eosin.

All histological sections were analyzed under light microscopy (Axioscop ${ }^{\mathrm{TM}}$,Carl Zeiss, Germany) and the following events were determined: presence of blood clot, inflammatory cell infiltrate, intensity of angiogenesis, bone formation and organization, resorption of graft material and closure of bone defects.

\section{RESULTS}

\section{0-day Period}

In the control group (blood clot), primary bone tissue formation occurred in hubcap form, which closed the cavity opening. In the region toward to the medullar canal, a thin bone layer was formed interlocked with connective tissue. Between the defect borders, there was a small amount of newly formed bone (Figure 1a). Callus bone tissue was observed covered by a dense periosteum. None of the defects presented connective tissue invagination.

The defects treated with Surgiplaster showed two tiny bands of primary bone tissue. The external band had a continuous aspect and the internal band had a fragmented aspect, between them there was connective tissue that was being replaced by myeloid tissue (Figure $1 b$ ). Between the defect borders, a small bone area was observed; however it did not close the defect and was thinner than the original bone tissue. In the more internal portion of the defect, there were some bone bands interlocked with a great amount of myeloid tissue, or tiny bone formations surrounded by cells and blood vessel-rich tissue.

In the defects treated with Capset bone trabeculae were formed and were projected to the middle of the defect along with the invaginated connective tissue.(Figure 1c). There was a bone tissue filling with thin and scattered bands, in addition to abundant connective tissue. There was neither bone callus formation in this group nor presence of periosteum or bone bands connected to the myeloid tissue.
Defects filled with Merck calcium sulfate showed connective tissue formation occupying partially the middle area of the defects. In this case, new bone formation occurred from the invaginated border to the medullar canal accompanying the margins of this connective tissue (Figure 1d).

\section{0-day period}

In the defects treated with blood clot, an intense bone tissue formation occurred from the defect borders, with a greater thickness. However, in all cases, the bone tissue in the defect central area was not as thick as in other areas, and sometimes was interrupted by a connective tissue bundle (Figure 2a).

The defects treated with Surgiplaster showed, in some cases, bone deposition extending from the defect border and several bone bands invading the medullar canal and demarcating spaces occupied by myeloid tissue. In the central region, connective tissue bundles were noticed, being replaced by bone tissue. In two cases, a tiny bone formation occurred in the defect border and the central region was occupied by myeloid tissue covered by connective tissue (Figure $2 \mathrm{~b}$ ).

Defects treated with Capset (Figure 2c) and Merck calcium sulfate (Figure 2d) were similar, that is, in three cases there was tiny bone formation in the border and a large central empty area occupied by connective tissue. In the other cases, the defect was closed by remodeling bone tissue, which was thinner than the original bone tissue.

\section{0-day and 180-day periods}

In both periods, the histological appearance was similar. In the defects filled with blood clot (Figure 3a), complete defect closure occurred by a compact arrangement of bone tissue projections thinner than the original cortical bone, with a small central depression. In the groups treated with Surgiplaster (Figure 3b), Capset (Figure 3c) and Merck calcium sulfate (Figure 3d), all the defects were filled with two compact bone corticals thinner than the defect borders with a central region occupied by myeloid tissue.

\section{DISCUSSION}

It has been shown that the hemihydrate calcium sulfate, also called, plaster of Paris, is safe and effective for a variety of clinical applications, such as medical and dental orthopedics $^{6,7,9,10,19}$. Moreover, calcium sulfate has also been used as a biological barrier in guided tissue regeneration, hindering physically the proliferation of connective and epithelial tissue cells from the bone defect, allowing bone regeneration by the principle of osteopromotion ${ }^{19,23}$. In the present work, the bone defects showed new bone formation in all studied groups, regardless of the commercial brand of the product used.

Surgiplaster, after 30 days, promoted the formation of thin bone trabeculae filled by a connective tissue being replaced by myeloid tissue. Merck and Capset calcium sulfate 
showed total or partial formation of a conjunctive fibrosis occupying the central area of the defect. In these cases, the newly formed bone from the defect border invaginated to the interior of the medullar canal following the edges of this
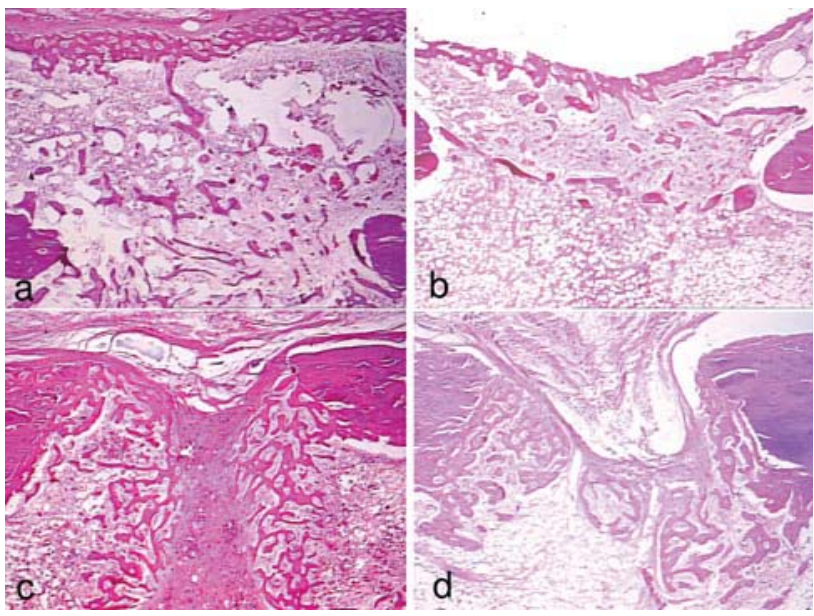

FIGURE 1- Period 30 days: a-Clot blood; b - Surgiplaster: c - Capset; d - Merk

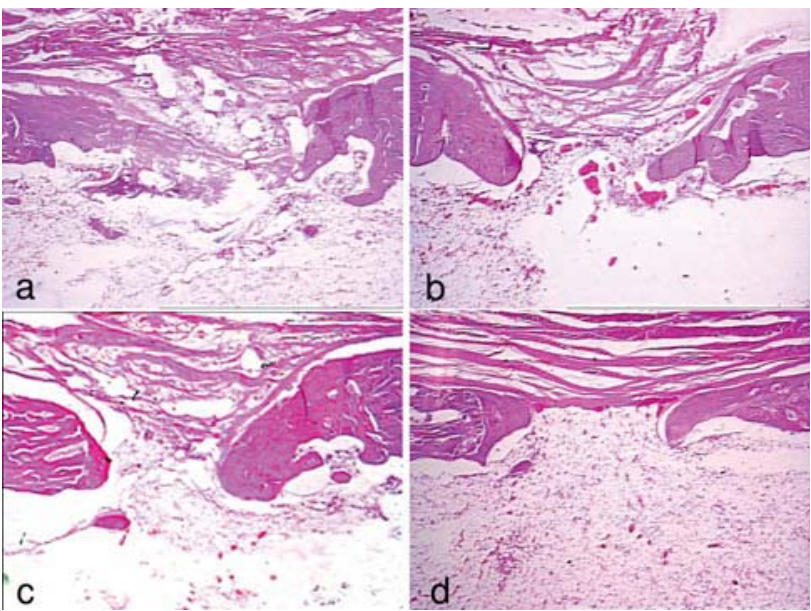

FIGURE 2- Period 60 days: a-Clot blood; b - Surgiplaster: c - Capset; d - Merk

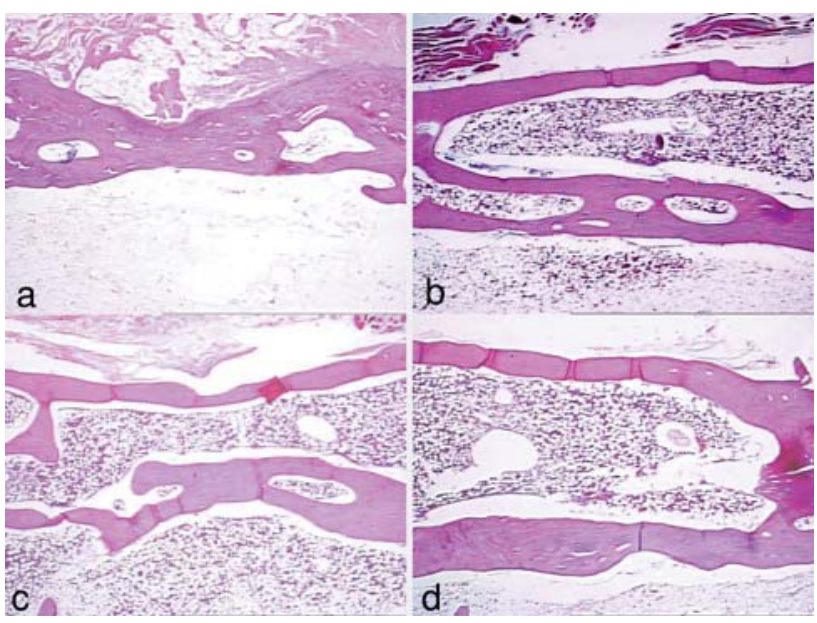

FIGURE 3- Period 180 days: a-Clot blood; b - Surgiplaster: c - Capset; d - Merk connective tissue. In these 30-day specimens, the presence of the calcium sulfate was not detected in the defective area. It is possible that a faster resorption of the material has contributed for connective tissue formation in the defect in cases filled with calcium sulfate from Merck and Capset. Due to the fact that the initial period was 30 days, it was not possible to know when this occurred and whether it could have some difference between materials.

Victor, et al. ${ }^{24}$ (1975), showed that the calcium sulfate was resorbed within 30 days and well tolerated by the organism. Murashima, et al. ${ }^{17}$ (2002) using Surgiplaster in bone defects prepared in jaws of Beagle dogs after apicoectomy did not observe the presence of Surgiplaster, 8 and 16 weeks after surgical interventions.

Some bone defects filled by Surgiplaster presented, after 60 days, formation of a disorganized bone tissue extending from the bone edge with innumerable bone projections that invaded the medullar canal and whose inter-trabecular spaces were occupied by myeloid tissue. The central region of the defect presented a connective tissue bundle being replaced by newly formed bone.

However, the bone defects filled with Merck and Capset calcium sulfate ( 3 cases each) presented little bone formation in the border and a great central portion filled with the connective tissue. In the other cases, closing of the bone defect due to formation of bone tissue thinner than the original bone, with presence of connective tissue occupying partially the central area of the defect. In these cases, the new bone formation from the border of the defect invaginated to the interior of the medullar canal following the edges of the connective tissue.

At 90 and 180 days, the defects presented similar histological appearance. In the groups treated with calcium sulfate, all defects were filled at the site of the original cortical by two parallel compact cortical bones, both thinner than the border of the defect, delimiting with the central region filled with myeloid tissue.

\section{CONCLUSIONS}

Surgical cavities filled with calcium sulfate revealed new bone formation in all studied groups, regardless of the commercial brand of the product used.

\section{REFERENCES}

1- Al Ruhaimi KA. Effects of adding resorbable calcium sulfate to grafting materials on early bone regeneration in osseous defects in rabbits. Int J Oral Maxillofac Implants. 2000;15(6):859-64.

2- Apaydin ES; Torabinejad M. The effect of calcium sulfate on hard tissue healing following periradicular surgery. J Endod. 2002;28(3):242-6

3- Bahn SL. Plaster: a bone substitute. Oral Surg Oral Méd Oral Pathol. 1966;21(5):672-81.

4- Beeson WH. Plaster of Paris as an alloplastic implant in the frontal sinus. Arch Otolaringol. 1981;107:664-9. 
5- Carneiro E. Análise microscópica descritiva do efeito do tamanho das partículas de matriz de osso medular bovino desmineralizado na reparação de defeito ósseo em fêmures de coelhos. 2003. 72p Dissertação (Mestrado) - Faculdade de Odontologia de Bauru, Universidade de São Paulo. Bauru; 2003.

6- Chogle S, Mickel AK. An in vitro evaluation of the antibacterial properties of barriers used in guided tissue regeneration. J Endod. $2003 ; 29(1): 1-3$

7- Couri C. Medical grade calcium sulfate hemihydrate versus expanded polytetrafluoroethylene in the treatment of mandibular class II furcation. J Periodontol. 2002;28(11):1352-9.

8- De Leonardis D,Pecora G. Prospective study on the augmentation of the maxillary sinus with calcium sulfate: histological results. J Periodontol. 2000;71(6):940-7.

9- De Leonardis D, Pecora G. Augmentation of the maxillary sinus with calcium sulfate: One year clinical report from a prospective longitudinal study. Int J Oral Maxillofac Implants. 1999;14(16):86978

10- Elkins AD, Jones LP. The effects of plaster of Paris and autogenous cancellous bone on the healing cortical defects in the femurs of dogs. Vet surg. 1988;17(2):71-8.

11- Frame JW. A composite of porous calcium sulphate dihydrate and cyanocrylate as a substitute for autogenous bone. J Oral Surg.. 1980;38:251-6.

12- Gitelis S, Piasecki P, Turner T, Haggard W, Charters J, Urban R. Use of calcium sulfate-based bone graft substitute for benign bone lesions. Orthopaedics. 2001;2:162-6.

13- Granjeiro JM, Taga EM, Fonseca M, Maeda L, Taga MSL, Trebacchetti CR et al. Hidroxiapatita para o uso clínico: caracterização físico-químico. Rev Gaúcha Odontol. 1992;40:130-4.

14- Jensen SS,Aaboe M, Pinholt EM, Hjorting-Hansen E, Melsen F, Rujter IE. Tissue reactions and material characteristics of four bone substitutes. Int J Oral Maxillofac Implants. 1996;11(1):55-66.

15- Kelly CM, Wilkins RM, Gitelis S, Hartjen D, Watson JT, Kim PT. The use of surgical grade calcium sulfate as a bone graft subsstitute: results of a Multicenter trial. Clin Orthop Rel Res. 2001;382:42-50.

16- Marx, R.E. Clinical application of bone biology to mandibular and maxilary reconstruction. Clin Plast Surg. 1994;21(3):377-92.

17- Murashima Y, Yoshikawa G, Wadaschi R, Sawada N, Suda H. Calcium sulfate as a bone substitute for various osseous defects in conjunction with apicoectomy. Oral Surg Oral Med Oral Pathol. $2002 ; 35: 768-74$.

18- Parsons JR, Ricci JL, Alexander H, Bajpai PK. Osteoconductive composite grouts for orthopedic use. Am NY Acad Sci. 1988;523:190207.

19- Pecora G, Baek SH, Rethnam S, Kim S. Barrier membrane techniques in endodontic microsurgery. Dent Clin North Am. 1997;41(3):585-601

20- Peltier LF. The use of plaster of Paris to fill defects in bone. Clin Orthop. 1961;21:1-31.

21- Santos FA. Implantes de biomateriais em alvéolos dentais. Estudo histológico em cães. 2000. 152p. Tese (Doutorado) - Faculdade de Odontologia de Araraquara, UNESP, Araraquara; 2000.

22- Sato S. Osteogenic response of rabbit to hydroxyapatite particleplaster of Paris mixture. Biomaterials. 1998;19(20):1895-900.
23- Sottosanti JS. Calcium sulfate: an available addition to the implant/ bone regeneration complex. Dent Implantol Update. 1993;9:25-9.

24- Victor JO, Santos Pinto R, Okamoto T, Castro AL. Implante de gesso Paris em alvéolos dentais. Estudo histológico em ratos. Rev Fac Odont Araçatuba.1975;4(1):71-5

25- Walsh WR, Morberg P, Yu Y, Yang JL, Haggard W, Sheath PC, Svehla M, et al. Response of calcium sulfate bone substitute in a confined cancellous defects. Clin Orthop. 2003;406:228-36. 